\title{
Promoting Successful and Sustainable Foreign Direct Investment through Political Risk Mitigation Strategies
}

Turning “Obsolescing Bargains” into Mutually Beneficial Arrangements

\author{
Lukas Vanhonnaeker ${ }^{1}$ \\ McGill University, Montréal, Québec, CANADA \\ lukas.vanhonnaeker@mail.mcgill.ca
}

\begin{abstract}
Political risk is a critical component of international trade and it is often the source of concern for businesses willing to invest abroad in light of the limited ability of legal instruments to protect them against it. That is why further political risk minimization has traditionally been done through investor-oriented strategies that maximize the interests of the investor. These interests sometimes clash with the interests of the State: the State seeks to promote sustainable development interests while the private investor is pursuing its own interests. These are the situations where it is necessary to avoid conflict by aligning the interests of the foreign actor with the local polity, which can be done through mutually beneficial (i.e. both for states and for private trade actors) political risk mitigation strategies. In this regard, this paper demonstrates how such strategies can incentivize international trade actors to undertake commercial operations in a sustainable manner.
\end{abstract}

1 Lukas Vanhonnaeker is a doctoral candidate at McGill University. He holds a BA in law at the Facultés Universitéaires Saint-Louis (Belgium, 2010) and a MA in law (cum laude) at the Catholic University of Louvain (Belgium, in 2012). Before enrolling at McGill University, he also received a LL.M. in international business law from the Free University of Brussels (Belgium, 2013). At McGill University, Mr. Vanhonnaeker pursued a LL.M. (2015). As a DCL candidate he is currently conducting research on international investment law, investor-state arbitration and international corporate law. The author thanks Professor Andrea Bjorklund for her suggestions and constructive comments on initial drafts of this article. 


\section{Keywords}

International investment law - Foreign direct investment - Obsolescing bargains Political risk - Political risk mitigation strategies - Political risk assessment Sustainable development

$[\mathrm{R}]$ ules are precisely worded in written formulae that readers or interpreters cannot change at their will. Nevertheless, all of them may go as soon and as abruptly as they came. The result is that, if we leave out of the picture the ambiguities of the text, we are always "certain" as far as the literal content of each rule is concerned at any given moment, but we are never certain that tomorrow we shall still have the rules we have today.

BRUNO LEONI ${ }^{2}$

\section{Introduction}

On the one hand, international economic law, as a field encompassing international trade and investment law, is composed of hundreds of treaties and agreements that have the purpose of regulating the behaviour of international trade actors in order to achieve the free movement of goods and capital. In particular, the law of international investment is composed of more than 3200 international investment agreements (IIAs) ${ }^{3}$ including bilateral investment treaties (BITS) and investments chapters of free trade agreements (FTAs) that are intertwined to form a complex web of instruments. While international investment law is often analysed from a legal perspective, whether focusing on the meaning of IIAs' provisions or their application by investment tribunals, the political aspect of foreign direct investment (FDI) is also critical. Legal and political considerations related to international investment law are embedded in a global economic context that is undergoing important changes: the traditional hierarchal model that places developed economies at the core of world affairs and emerging nations at the periphery erodes away and is replaced by a model "in which [emerging markets] countries contribute a bigger share to global gross domestic product than their developed counterparts, when mea-

2 Bruno Leoni, Freedom and the Law (3rd ed., Liberty Fund, Inc. 1991) at 74-75.

3 In its 2015 World Investment Report, UNCTAD identified 3,271 IIAs at the end of 2014 (UNCTAD, World Investment Report 2014: Reforming International Investment Governance, 2015, available at http://www.unctad.org/ (accessed 9 December 2015) at 106). 
sured by purchasing power". ${ }^{4}$ Acknowledging this evolution is critical to "allow institutions, companies and multilateral organisations to assess more accurately the balance of risk and opportunity in large parts of the world". ${ }^{5}$

On the other hand, sustainable development, which can be broadly defined as "development which meets the needs of the present without compromising the ability of future generations to meet their own needs", ${ }^{6}$ rapidly became an essential component of international trade policy ${ }^{7}$ and part of the major trade agreements at the wTo level and in other bilateral and regional trade agreements. ${ }^{8}$ Sustainable development is linked to environmental protection, ${ }^{9}$ but also encompasses economic and social development. These intersecting policy objectives tend to be long term and focused on the polity as a whole and effectuated by state measures, whereas trade and investment objectives tend to be focused on the shorter term and effectuated by the individual traders and investors and achieved via constraints on states.

Political risk, a critical component of any international trade operation, can be defined as "threats to the profitability of a project that derive from some sort of governmental action or inaction rather than from changes in economic

4 James Kynge and Jonathan Wheatley, "Emerging markets: Redrawing the world map", Financial Times, August 3, 2015.

5 Ibid.

6 Gro H. Brundtland et al., Our Common Future: The Report of the World Commission on Environment and Development (Oxford University Press 1987) at ix.

7 See e.g. Rosalyn Higgins, "Natural Resources in the Case Law of the International Court", in Alan Boyle and David Freestone, International Law and Sustainable Development: Past Achievements and Future Challenges (Ou 1999) at 87.

8 For example, the wTo embraced the concept of sustainable development by mentioning it in the Preamble of the wто Agreement in 1992 and further highlighting it in subsequent declarations such as the 1998 Geneva Ministerial Conference Declarations:

"[W]hile allowing for the optimal use of the world's resources in accordance with the objective of sustainable development, seeking both to protect and preserve the environment and to enhance the means for doing so in a manner consistent with their respective needs and concerns at different levels of economic development."

(wTo Agreement, Preamble).

"We shall also continue to improve our efforts towards the objectives of sustained economic growth and sustainable development."

(Geneva Ministerial Declaration, wTo Document WT/MIN(98)/DEC/1, 25 May 1998, at para. 4).

9 Marie-Claire Cordonier Segger and Ashfaq Khalfan, Sustainable Development Law: Principles, Practices \& Prospects (Oxford University Press 2004) at 16. 
conditions in the marketplace". ${ }^{10}$ Accordingly, political risks manifests itself through the actions of the state and must be distinguished from damages suffered by the investor by reason of factors external to the actions of the state "caused by the commercial realties of supply and demand or by natural disaster".1 International investment law, which is particularly subject to political risk, ${ }^{12}$ deals with legal risk (and to a lesser extent political risk) and have

10 Theodore H. Moran, "Political and Regulatory Risk in Infrastructure Investment in Developing Countries: Introduction and Overview", 5(6) CEPMLP Journal, at 3 [citing Harvard Professor Louis Wells, Jr.] (as cited in Noah Rubins and N. Stephan Kinsella, International Investment, Political Risk and Dispute Resolution: A Practitioner's Guide (Oceana Publications 2005) at 3). In particular, Williams divides political risks into three categories: risks of political violence; risk that the host state undertakes deliberate acts; and, risks that the conversion of local currency into foreign exchange is restricted (S. Linn Williams, "Political and Other Risk Insurance: OPIC, MIGA, Eximbank and Other Providers" (1993) 5 Pace Int'l L. Rev. 59, at 64-65).

11 Rubins and Kinsella, op. cit., at 3. It is indeed important to make a distinction between intentional interference of the host state with the investment and interference that finds its roots outside the host state's control:

"Obviously, we do not inhabit a world of complete certainty. We cannot predict all of our future actions and their outcome. There are in our world surprises. Our knowledge of future events and outcomes is less than perfect. We make errors, can distinguish between failure and success, and are capable of learning. Unlike for an automaton, for us knowledge is valuable. To know something or not makes a difference. (...) Knowledge does not help us predict an unalterable course of events but is a tool of purposefully changing and hopefully bettering future outcomes and events."

(Hans-Hermann Hoppe, "On Certainty and Uncertainty, Or: How Rational Can Our Expectations Be?" (1997) 10(1) Review of Austrian Economics 49, at 49-50).

The difficulty arising from this distinction is that in practice, a number of factors lead to interference with an investment that originate both within and outside the host government's control.

See Williams, op. cit., at 62:

"While every investment, domestic or foreign, entails (...) political risks, the risks of international investment, particularly in developing countries, are generally greater and more complex than those for domestic investments. (...) The political risks of international investment $(. .$.$) particularly in developing countries, are generally without parallel$ in a domestic environment. For domestic investments, there is often a so-called "regulatory risk" that the government will change the rules of the game in a way that will adversely affect the economics of the investment. [footnote omitted]."

With respect to domestic investments, such political risk is often referred to as "regulatory risk" and is of a lesser extent as access to information is easier to the domestic investor that also has an easier access to structures allowing him to resolve disputes compared to foreign investors that often fear that the degree of impartiality of such structures, including the judiciary, will not be the same as the one the domestic investor can expect; hence the recourse to international arbitration as first mean of resolving international 
constraints on actors to minimize legal (and political) risks. Further political risk minimization has traditionally been done through investor-oriented policies that maximize the interests of the investor. These interests sometimes clash with the interests of the state: the state seeks to further sustainable development interests while the private investor is pursuing its own interests. These are the situations where it is necessary to avoid conflict by aligning the interests of the foreign actor with the local polity, which can be done through political risk mitigation strategies. In those cases the interests of the investor are more clearly juxtaposed with the interests of the local polity.

The purpose of this paper is to push this argument even further and to demonstrate how political risk assessment and political risk mitigation strategies can incentivize international trade actors to undertake commercial operations in a sustainable manner and thus benefit both the investor and the host state. In order to provide a clear understandings of the advantages of mutually beneficial risk mitigation strategies, this paper will first provide an overview of what are political risk and "obsolescing bargains" in the field of international investment law together with the rationale of political risk assessment and what it entails. The paper will then analyse risk mitigation strategies that investors can adopt by emphasising the importance of opting for mutually beneficial strategies that both mitigate political risk for investors and contribute to the development of host states.

\section{Political Risk and Political Risk Assessment in International Investment Law}

\subsection{Political Risk in International Investment Law}

Political risk finds its roots in the inherently unpredictable conduct of both humans and governments:

Future needs and valuations, the reaction of men to changes in conditions, future scientific and technological knowledge, future ideologies and policies can never be foretold with more than a greater or smaller degree of probability. Every action refers to an unknown future. It is in this sense always a risky speculation. ${ }^{13}$

investment disputes. Such considerations are especially relevant, and often constitute investors' main concern, when the host state is a developing country.

13 Ludwig von Mises, Human Action-A Treatise on Economics (The Ludwig von Mises Institute 1998) at 106. See also Jeswald W. Salacuse, The Three Laws of International 
In the field of international investment law, a change of behaviour on the part of governments often requires "States [to] engage in a variety of actions that can cause loss for foreign investors". ${ }^{14}$ In order to diminish risks associated with unpredictable behaviour, the law is meant to provide for a precise and delimited framework within which human and governmental conduct can take place.

According to Max Weber, in order to achieve what he coined as the "calculability" of transactions and thus to meet the requirements of a capitalist economy: "a promptly and predictably functioning legal system", ${ }^{15}$ three items must be present:

Weber seems to have had especially three items in mind when he referred to calculability in this context: (a) that the legal text lends itself to prediction; (b) that the administration of the law is not arbitrary; and (c) that contracts are legally enforced. ${ }^{16}$

The corpus of bilateral and multilateral agreements that compose what is broadly known as international investment law was created with the precise aim of enhancing legal certainty by providing a framework that would delimit what investors and host states can and cannot do. Political certainty, however, is much more difficult to ensure. Indeed, while legal loopholes can be filled through the enactment of new legal documents or binding interpretations of existing ones, an inherently vague concept such as "behaviour" can only with difficulty be calculated in advance and it is only when the behaviour becomes apparent that the appropriate measures can be taken. The critical difficulty associated with human and governmental behaviour is that regardless of the

Investment: National, Contractual, and International Frameworks for Foreign Capital (ou P 2013) at 25:

"It is the inherent unpredictability of human and government conduct that creates perceived risk for a contemplated investment."

14 Rubins and Kinsella, op. cit., at 2. Such actions can take many forms including the seizure of investors' assets, the breach of an agreement with an investor, the imposition of new regulatory conditions, the outlawing of the investment or the raising of taxes. The implementation of any such measures by the host government by virtue of its sovereign power are what is known as "political risks."

15 Max Weber, Economy and Society, in Dirk Käsler, Max Weber: AN Introduction to His Life and Work (University of Chicago Press 1988) at 146.

16 Richard Swedberg, "Max Weber's Contribution to the Economic Sociology of Law" (2006) 2 Anny. Rev. Law Soc. Sci. 61, at 69 . 
legal framework, it will adapt and change according to the general context, both legal and political.

This phenomenon is particularly well illustrated by one of the key concepts of this paper: the "obsolescing bargain". This concept, coined by Raymond Vernon, "suggests that the very nature of investment and the effect of risk drives governments to increase interference or decrease support over time visà-vis foreign investment". ${ }^{17}$ In particular, it refers to two factors: a change in circumstances (1) and the host government's increased bargaining power (and, conversely, the investor's decreased bargaining power) after the making of the investment (2).

As far as the first factor is concerned, a change in circumstances can lead the host government to change its behaviour and develop new policies that are not necessarily aligned with the policies in place at the time of the investment. Such a behaviour will typically arise when the net costs of performance exceeds the net benefits perceived by the host government. In other words, host governments are likely to change their attitude towards a given investor once it becomes less expensive for them to non-perform than to continue to respect their obligations. ${ }^{18}$ The second factor, on the other hand, consists in a shift in the bargaining power:

At the outset of a project, foreign investors tend to demand additional concessions or higher returns as a result of the perceived risks of entry and the intensive exposure of the start-up phase. Once the investment is underway, however, the host government is less prepared to maintain the start-up conditions, since the risk often will have declined, along with the cost of financing. ${ }^{19}$

17 Rubins and Kinsella, op. cit., at 5 .

18 A good example of such a scenario can be found in the dispute opposing ssP Ltd. and Southern Pacific Properties Ltd. against Egypt (Southern Pacific Properties (Middle East) Limited v Arab Republic of Egypt, ICSID (W. Bank) case no. ARB/84/3, ICSID Rev.-FILJ 328 (1993)). The two companies undertook an investment involving the construction of a luxury resort near the Giza pyramids in Egypt. While the Egyptian government initially welcomed the project for its economic benefits, roughly three years after the signature of the contract authorizing the construction of the resort, the project "began to encounter political opposition in Egypt and it became the subject of parliamentary inquiry. Opponents of the project claimed that it posed a threat to undiscovered antiquities" (para. 62). The Egyptian government, judging that the political cost linked with the project outweighed the economic benefits of the investment, cancelled it and was later held liable for the interference with the investment and had to compensate the investor (see para. 257).

Rubins and Kinsella, op. cit., at 5 . 
Furthermore, the increase in the host government's bargaining power will be proportional to the duration of the investment:

Where a project is long-term with heavy capital investment (sunk costs) at the start, and uses assets that are not easily sold or converted to other purposes, the government has a great deal of leverage over the foreign investor, who cannot credibly threaten to abandon his investment plans if conditions deteriorate. This imbalance creates an almost irresistible temptation for local officials to extract short-term political advantage by shifting foreign investment profits to constituents either within the government or the public at large. ${ }^{20}$

International investment law cannot alter this shift in the bargaining power that is not rooted in purely legal considerations. However, what it can do, and to a certain extent does, is to limit what the host government, that has the leverage in the post-investment investor-state relationship, can do. As explained above, the ability of international investment law to do so is however limited, as demonstrated in practice with the increasing number of cases that are initiated each year and which are the result of the exercise by host governments of their higher bargaining power compared to that of the investors. ${ }^{21}$ Behaviour is something that remains, inherently unpredictable albeit taking place within a given framework. Hence the importance of political risk assessment, i.e. to "measure" the political risk.

\subsection{The Contours of Political Risk Assessment}

Political risk assessment is not an easy undertaking as numerous factors must be taken into account, ranging from the domestic legal regime of the host state and its trade-related international obligations to its economic, political, cultural and historical characteristics, which often requires having an extensive knowledge of the host state itself.

\footnotetext{
20 Ibid.

21 See ICSID, 2014 Annual Report, available at https://icsid.worldbank.org/apps/ICSIDWEB/ resources/Documents/ICSID_AR14_ENG.pdf (accessed 9 December 2015) at 5:

"The number of cases registered in fiscal year 2014 remained steady, with 40 new ICSID cases and 8 new cases for administration under the UNCITRAL Arbitration Rules. Over the year, the Centre administered 209 cases, the most cases ever administered in a single fiscal year."
} 


\subsubsection{What Must be Taken Into Account \\ 2.2.1.1 The Legal Regime of the Host State}

The first and most obvious factor that must be taken into account in political risk assessment is the legal regime of the host state. As observed by Malcom D. Rowat, investors should look for a "well-developed legal and regulatory framework, including favourable tax and labor codes, investment laws, property laws, the protection of intellectual property rights, and competition policy, as well as relative industrial deregulation" 22 that will determine the degree of the political risk associated with an investment in this particular host state. Moreover, the existence of a well-developed legal and regulatory framework should be ideally accompanied by the presence of an independent judiciary that interpreted and applied these rules. Such a well-developed legal and regulatory framework interpreted through substantial jurisprudence provides, indeed, less leeway to the host state willing to interpret and apply the existing framework in its favour and against investors' interests. Conversely, lacunae in a given legal framework are a strong indicator of a high degree of political risk as, in the absence of a well developed set of laws and regulations, nothing can guarantee that the host state will not regulate in its interest and interfere with an investment. Similarly, an existing legal framework that has not been interpreted and applied in a substantial manner signals a higher degree of political risk.

When assessing political risk, investors should pay particular attention to specific aspects of the host state's regulatory framework such as the property rights regime or tax laws. However, investors should also enquire about local laws regulating foreign investments as some countries might, for example, share a more expansive view of what a government can lawfully expropriate and what compensation must be paid. Not all countries have such laws, but where they exist, they will often provide valuable information with respect to political risk. For example, domestic laws regulating FD I provide for circumstances in which the expropriation of a foreign investment can take place and

22 Malcolm D. Rowat, "Multilateral Approaches to Improving the Investment Climate of Developing Countries: The Cases of ICSID and MIGA" (1992) 22: 1 Harv. Int'l L.J. 103, at 104. In addition, according to the author, the following other factors contribute to a favourable foreign investment climate:

“(1) overall macroeconomic stability, including relative consistency in prices, exchange rates, and trade policies; (...) (3) a sufficient infrastructure, including relatively comprehensive transportation, power, and telecommunications systems, as well as available housing and qualified human capital; and (4) overall political stability. (Id.)." 
under what conditions. ${ }^{23}$ Others establish tax incentives for investments in specific sectors, ${ }^{24}$ encourage investments via the creation of joint ventures ${ }^{25}$

23 For example, Section 25(1)(2) of the Czech Republic Commercial Code of 1992 (Act 513/1991), titled "Protection of Property of Non-Residents Conducing Business in the Slovak Republic", provides that

(1) A non-resident-s property related to the business conducted in the Slovak Republic and the property of a legal entity with foreign shareholding referred to in Section 24 subsection 1 above may only be nationalized in the Slovak Republic and the ownership title thereto may only be restricted by an act of Parliament and in the public interest, provided that there is no other alternative for satisfying such public interest. An appeal may be filed with a court against the decisions above.

(2) If measures are taken pursuant to subsection 1 above, an indemnity must be paid without delay reflecting the full value of the property affected by any such measure at the time of its implementation. The indemnity shall be paid in foreign currency and shall be freely transferable abroad. [emphasis added].

In comparison, section 11(1)(2) of the Namibia Foreign Investment Act of 1990 (Act to make provision for the promotion of foreign investments in Namibia, signed by the President on 10 December 1990, as amended by Act No. 24, 1993, Foreign Investment Amendment Act 1993) provides that

(1) No enterprise, or part of an undertaking carried on by an enterprise, or interest in or right over any property forming part of such undertaking shall be expropriated except in accordance with the provisions of Article 16 (2) of the Namibian Constitution.

(2) Where an enterprise or any part of an undertaking carried on by an enterprise, or any interest in or right over any property forming part of such undertaking is expropriated, the Government shall pay to the holder of the Certificate just compensation for such expropriation without undue delay and in freely convertible currency. [emphasis added]. See e.g. Clause 5 (para. 2) of Azerbaijan's foreign investment law (Law of the Azerbaijan Republic About Protection of Foreign Investments, 1992, No. 57):

"Additional tax privileges and other privileges might be established for foreign investments in the priority spheres of economy of the Azerbaijan Republic and also on specific territories thereof."

25 See e.g. Clause 26 of Azerbaijan's foreign investment law (Law of the Azerbaijan Republic About Protection of Foreign Investments, 1992, No. 57):

"Property delivered to the territory of the Azerbaijan Republic as the share of foreign partner being contributed to the Partnership fund of Joint Venture is completely exempted from custom duty and is not subject to import tax.

Property delivered to the Azerbaijan Republic by foreign employees of the enterprise with foreign investments for their own use is exempted from custom duty." 
or establish international arbitration as a mandatory settlement mechanism of investment disputes. ${ }^{26}$

However, such domestic regulations, whether governing the tax law regime, property rights or FDI itself, keep the status of local laws. Accordingly, not only do they still leave room for potential political risk if they have been applied and interpreted only occasionally. But, in addition, they are also enforceable by local courts that can be pressured by the state when interpreting and applying them or simply be altered by the host state by virtue of its sovereign regulatory power.

\subsubsection{The International Regime Regulating FDI}

The second factor that foreign investors must take into account is the applicable international regime regulating foreign investments. This regime consists of the BITs and other agreements regulating FDI (generally referred to as "international investment agreements", or, "IIAs") to which the host state is a party. These instruments are very important for political risk assessment as they provide for the regulatory framework for FDI and establish the outer limits within which the host state will be able to exercise its sovereign regulatory power with respect to FDI. IIAs insure a certain degree of predictability and reduce political risk by protecting foreign investors through standards of protection including the prohibition of indirect expropriation, the national treatment (NT) standard of protection, the most-favoured-nation (MFN) principle or the fair and equitable (FET) standard of protection. ${ }^{27}$ The violation by the

26 See e.g. Section 23 of the Tanzania Investment Act of 1997 (Tanzania Investment No. 26): 23.-(l) Where a dispute arises between a foreign investor and the Centre or the Government in respect of a business enterprise, all efforts shall be made to settle the dispute through negotiations for an amicable settlement.

(2) A dispute between a foreign investor and the Centre or the Government in respect of a business enterprise which is not settled through negotiations may be submitted to arbitration in accordance with any of the following methods as may be mutually agreed by the parties, that is to say-

(a) in accordance with arbitration laws of Tanzania for investors;

(b) in accordance with the rules of procedure for arbitration of the International Centre for the Settlement of Investment Disputes;

(c) within the framework of any bilateral or multilateral agreement on investment protection agreed to by the Government of the United Republic and the Government of the Country the Investor originates.

27 On the traditional standards of protection under international investment law, see generally August Reinisch (ed.), Standards of Investment Protection (oup 2008) and Rudolf Dolzer and Christoph Schreuer, Principles of International Investment Law (2nd ed., oup 
host state of any of these standards exposes the later to investor-state arbitration (ISA), the common means of dispute resolution in the realm of international investment law. Accordingly,

[w]here a potential investment locale is subject to an applicable investment treaty, the foreign investor can enjoy greater confidence that unreasonable government interference with his activities will be minimized. ${ }^{28}$

However, while host governments are less likely to engage in unpredictable and detrimental conduct if they are bound by such treaties, political risk remains a concern as, ultimately, these treaties do not alter the sovereignty of states that remain free to regulate when they deem it necessary even if it is in fine detrimental to the foreign investor. In this regard, investor-state arbitration case law is probably the best example of host states regulating in a detrimental manner with respect to foreign investors despite being bound by an investment treaty. ${ }^{29}$

\subsubsection{Additional Factors}

A last category of factors that must be taken into account in political risk assessment consists of a variety of aspects that are specific to the host state and that include the economic and political situation of the country as well as its cultural and historical features.

$\left({ }^{*}\right)$ Economical aspects include, for example, economic stability (in the short and long term $)^{30}$ and the host state's sovereign debt and balance of payments; ${ }^{31}$

2012). It is noteworthy that in the context of a dispute, political risk assessment, that plays an important role in the creation of the investor's reasonable expectation, can be key in the framing of a FET arguments as this traditional standard of protection revolves around the notion of "legitimate expectations".

28 Rubins and Kinsella, op. cit., at 28.

29 It is noteworthy that during the 2014 fiscal year, $28 \%$ of the ICSID (International Centre for Settlement of Investment Disputes) arbitration were concluded by an award upholding claims in part or in full against $24 \%$ of the awards dismissing all claims and $48 \%$ of the cases in which the tribunal declined jurisdiction (see ICsID, 2014 Annual Report, op. cit., at 30$)$.

$30 \quad$ See Rowat, op. cit., at 104.

31 Such economical aspects that could lead a host state to regulate and interfere with an investment include financial crises; perceived economical necessity (for example if the host state's economy becomes excessively dependant on outsiders or if foreign investors become excessively influential in the host state). 
$\left({ }^{*}\right)$ Political aspects include, for example, the host state's political structure and system such as the election process, the division of the political power among the different branches of the government and the host state's policies; ${ }^{32}$

$\left({ }^{*}\right)$ Cultural and historical aspects include, for example, the host state's approach toward various concepts such as that of property rights, its history of protecting property rights and the experience of previous foreign investors in the host state.

\subsubsection{Who Should Undertake Political Risk Assessment}

As observed above, these factors of political risk require having an extensive knowledge of the host state itself. Accordingly, businesses are likely to lack the required knowledge to undertake political risk assessment themselves and should seek advice from competent and, ideally, local counsel. An additional hurdle to "self-political risk assessment" is the fact that in order to be efficient, the investor must first "identify and attach values to specific factors that can affect an investment". ${ }^{33}$ This process often appears to be very risky for investors because it leads them to attach specific attention to some factors that are important to them and that they feel might affect their investment without necessarily undertaking a global risk assessment that would provide them with

32 See Michael A. Geist, "Toward a General Agreement on the Regulation of Foreign Direct Investment" (1995) 26 Law \& Pol'y Int'l Bus. 673, at 686, fn 65:

"Although political stability is not a prerequisite for FDI, past investment trends indicate that investors are more likely to invest where there are assurances that the legal or political framework is not likely to undergo radical alteration."

Such political aspects that could lead a host state to regulate and interfere with an investment include political crises; changes in government or ideology (for example if a nationalist government replaces a socialist government such as in the Indian state of Maharashtra in 1993 when the newly elected nationalist government cancelled electric power development agreements that the previous government signed with an American corporation, Enron Corp. A similar situation occurred in Venezuela under the Presidency of Hugo Chavez that enacted measures intended to renegotiate agreements in the petroleum sector); the host state's foreign policy (for example, retaliation measures, such as those enacted by Cuba and Libya against the United States, are likely to interfere with investments); and, the modification by the host state of its law to enhance public welfare (for example, Uruguay, and then Australia enacted so-called "plain-packaging" legislations to limit cigarette advertising).

See generally Richard P. Teisch and William A. Stoever, "Enron in India-lessons from a renegotiation" (1999) 35(1) Mid-Atlantic Journal of Business 51 and Julián Cárdenas García, "Rebalancing Oil Contracts in Venezuela" (2011) 33 Hou. J. Int'l L. 235. 
an overall picture of the political (in)stability of the host state. Ultimately, such targeted assessments showcase subjective drifts which led some to describe the political risk assessment undertaken by managers as more of an "art than a science": ${ }^{34}$

First, it is clear that managers consider political instability or political risk, typically quite loosely defined, to be an important factor in the foreign investment decision. Second, it is just as clear that rigorous and systematic assessment and evaluation of the political environment is exceptional. Most political analysis is superficial and subjective, not integrated formally into the decision making process, and assumes that instability and risk are one and the same. The response frequently is avoidance; firms simply do not get involved in countries, or even regions, that they perceive to be risky. Last, managers appear to rely for environmental information primarily on sources internal to the firm. When they look for outside data, they are most likely to go to their banks or the general and business media. ${ }^{35}$

Alternatively, foreign investors can also have recourse to a political risk assessment service and seek advice from organizations such as the Multilateral Investment Guarantee Agency (MIGA) or the Overseas Private Investment Corporation (OPIC) in the United States that specialize in political risk assessment and that provide up-to-date information about political risk in given countries. ${ }^{36}$ Another organization, The Economic Intelligence Unit, also provides detailed information about the political and economic situation in more than 180 countries ${ }^{37}$ across Africa and the Middle East, the Americas, Asia and Europe. Country specific reports include information about the political structure of the country; its economic structure indicators (annually and quarterly); its political stability; its international relations; its policy trends; its fiscal policy; its monetary policy; its economic growth and many others. Furthermore, this information is regularly updated. The Economic Intelligence Unit also

\footnotetext{
34 Ibid.

35 Stephen J. Kobrin, "Political Risk: A Review and Reconsideration" (1979) 10(1) Journal of International Business Studies 67, at 75. See also Alan C. Shapiro, "Managing Political Risk: A Policy Approach" (1981) Columbia Journal of World Business 63.

$36 \quad$ On such institutions, see generally Williams, op. cit.

37 See The Economic Intelligence Unit, http://country.eiu.com/AllCountries.aspx (accessed 9 December 2015).
} 
monitors credit and operational risks in more than 180 markets ${ }^{38}$ and provides projections and forecast updates.

A similar service is offered by the PRS Group that assesses and forecasts political and country risk; ${ }^{39}$ the Business Environment Risk Intelligence, that provides its clients with forecasts about more than 140 countries; ${ }^{40}$ and, the Control Risks Group that specialises in helping organisations to manage political, integrity and security risks in hostile environments. ${ }^{41}$

Finally, foreign investors should always consider enquiring about the economical and political aspects of a given country from the foreign mission of their home state as the latter often prepares local reports on the basis of accurate information.

\section{Mutually Beneficial Sustainable Development-based Strategies to Respond to Political Risk}

In the field of international economic law and in particular in international investment law, the protection of private businesses against host state interference has always been one of the key objectives. First achieved through "gunboat diplomacy"42 and diplomatic protection, ${ }^{43}$ the protection of private trade actors undertaking operations in an international context then evolved into a legal framework composed of trade agreements. Nevertheless, the inherently protean nature of political risk makes it difficult to contain via legal instruments. However, strategies exist ${ }^{44}$ to mitigate political risk, some of which can

38 See The Economic Intelligence Unit, http://www.eiu.com (accessed 9 December 2015).

39 See The PRS Group, https://www.prsgroup.com (accessed 9 December 2015).

40 See Business Environment Risk Intelligence, http://www.beri.com (accessed 9 December 2015).

41 See Control Risk Group, https://www.controlrisks.com (accessed 9 December 2015).

42 Surya P. Subedi, International Investment Law (Hart Publishing 2008) at 11-12.

43 Id., at $12-13$.

44 These do not include insurances against political risk from third parties actors such as governmental agencies and private companies but also by international organizations, among which the MIGA, that is affiliated to the World Bank, stands as one of the most often sought (for more information about the services the MIGA provides, visit https:// www.miga.org, accessed 9 December 2015), or the OPIC (https://www.opic.gov, accessed 9 December 2015), in the United States, that provides for political risk insurance. In addition, investor should consider other types of insurance mechanisms such as credit default swap for specific types of investments such as foreign sovereign bonds. It is noteworthy, however, that these insurances from third parties are often limited to specific political 
be framed as mutually beneficial as they are rooted in sustainable development and aim primarily at protecting private actors from political risk but in doing so, also serve the interests of the host state.

\subsection{The One-sided "Aggressive" Approach: The Hostage Position}

Traditional risk mitigation strategies can be described as "aggressive" as they have no positive effects for states: they are one-sided and serve the sole interests of investors. ${ }^{45}$ These strategies can be structural or contractual and can include structuring an investment via the use of subsidiaries so that only the critical assets necessary for the investment are within the foreign state's territory. ${ }^{46}$ Involving other foreign private actors in the overall operation can also act as a deterrent for the host state to interfere with a project "since multinational participation would lead to diplomatic difficulties with numerous foreign countries". ${ }^{47}$ Undertaking an investment through subsidiaries and including other actors in the overall operation also has the advantage, if the subsidiaries and/or other actors are incorporated in a third state, to make the investment benefit from the protection of eventual international investment agreements in force between the third country and the host state.

risks such as currency inconvertibility and transfer restriction; expropriation; war, terrorism and civil disturbance; branch of contract; and, the non-honoring of financial obligations.

45 For instance, keeping assets such as technology outside of the host state's territory does not allow local populations to benefit from it.

46 These structures rely heavily on the use of subsidiaries established outside the host state's territory:

"One threshold alternative to consider, in counties where it is permitted, is to conduct the business in the host country through a branch of a U.s. or other foreign corporation. The principal value of this type of organization from the expropriation perspective is that it creates the most clear and simple foundation for the claim that those assets of a foreign company that have situs outside the host country are not subject to expropriation by the host country."

(Philip R. Stansbury, "Planning Against Expropriation” (1990) 24 Int'l L. 677, at 678-679).

Such structures can involve segregating assets into separate legal entities and keeping non-indispensable components, raw materials or other supplies outside the host state's territory to reduce the risk of nationalisation or expropriation. Private actors can also consider, for example, undertaking the production phase within the host state's territory and the processing phase outside the latter's territory.

Salacuse, op. cit., at 147 . 
An example of a corporate structure allowing for political risk mitigation is the case Mexicana de Cobre, SA (commonly referred to as Mexcobre). ${ }^{48}$ Mexcobre, a Mexican copper producer, engineered off-shore dollar financing to answer, among others, the concerns of banks regarding country-specific political risk. In particular, banks were worried that the exercise of governmental control over Mexican firms would lead to prevent the monthly payment of the principal and interest that, in the case at issue, amounted to $\$ 8$ million on a \$210 million three-year loan Mexcobre negotiated and obtained from a syndicate of international banks led by Banque Paribas. ${ }^{49}$ In order to mitigate the political risk at issue in this operation, Mexcobre undertook an innovative financing deal that combined a commodity swap with a long-term sales contract pursuant to which SOGEM, a European copper buyer, agreed to buy 4,000 metric tons of Mexcobre's copper output every month (this roughly amounted to one third of Mexcobre's copper output). Under this contract, SOGEM was to make its monthly payments for the copper into Parisbas' New York-based escrow account and Banque Parisbas would automatically deduct the company's monthly loan payments from the account, which "effectively eliminated both the risk of devaluations of the Mexican peso (exchange risk) and the possibility that the Mexican central bank would not make dollars available to repay the loan (country risk)" ${ }^{50}$

In addition, besides structuring the investment prior to undertaking it, the investor might need to change the structure of the operation if it becomes necessary. Indeed, if "it is unusual for an investor to be surprised by a published expropriation decree or the appearance of government officials to take possession", 51 the investor must know how to respond. There are several ways of protecting an investment against political risk while the former is underway. These mainly involve reducing the volume of operations undertaken in the host country, move assets such as equipment and inventory but also

48 On this example, see generally Laurent Jacques and Gabriel Hawawini, "Myths an Realitites of the Global Capital Market: Lessons for Financial Managers" (1993) 6(3) Journal of Applied Corporate Finance 81, at 89-90.

In particular, the interest rate was $11.5 \%$ (three-year LIBOR plus $3 \%$ ) for 36 months, which was in the advantage of Mexicobre as this interest rate was considerably lower than the 20\%-plus interest rate Mexcobre carried on its existing debt.

$50 \quad$ Jacques and Hawawini, op. cit., at 90 .

$51 \quad$ Richard M. Mosk, "Expropriation: What to Do About It?" (1993-1994) 5 Calif. Int'l Practitioner 11, at 16 . 
currency out of the host state's territory ${ }^{52}$ and reduce capital flows into the host state. ${ }^{53}$ Investors can also freeze banking operations within the territory of the host state ${ }^{54}$ and ideally keep detailed records of all their operations. ${ }^{55}$ Finally, investors can play the diplomatic card and inform their home government of a threat of expropriation or any other interference with their investment as the involvement of the investors' home states may act as a deterrent with respect to the host state's intention to interfere with the investment.

As far as contractual means of alleviating political risk are concerned, investors have a panoply of clauses at their disposal that they can negotiate into the investment contract in order to reduce the risks of interference with their investment. These provisions include choice of law clauses; stabiliza-

$5^{2}$ See Stansbury, op. cit., at 680:

"It is sometimes possible to structure import arrangements so that even goods on the high seas that are not yet paid for by a company incorporated in the host country can be diverted, if necessary, after an expropriation. One way of so doing might be to retain title to the goods in another foreign entity, not owned by the target company, until they reach the receiving port in the host country. [footnote omitted]."

However, in such circumstances, the host state can respond by suspending payments and restricting withdrawals. This is precisely what happened during the 2001-2002 Argentinean financial crisis: after a global mistrust in the Argentinean banking systems, investors undertook massive deposit withdrawals which eventually led Argentina to suspend its payment on its external debt and restrict deposit withdrawals. See generally J.F. Hornbeck and Meaghan K. Marshall, "The Argentine Financial Crisis: A Chronology of Events", Report for Congress, Updated June 5, 2003.

53 It is noteworthy that in case the investment involves the supply of a public or vital goods, the host state might be more incline to seize the investment in light of the investor's attempt to pull out of the country.

54 In addition, if necessary, the investor can consider seeking injunctive relief. See John N. Hazard, "Risks in Investing in the Uss R: Can There be Protection Against Them?" (1990) 11 N.Y.L. Sch.J. Int'l \& Comp. L. 457 , at 458 (the author notes, about investing in the USSR that "a (...) firm doing business always tries to have a payment to withhold or a service that can be postponed until the Soviet side performs").

See Stansbury, op. cit., at 683:

"An expropriation case is a highly detailed factual case in which the company must prove income, cash flow, assets, and values, in addition to defending against counterclaims. Once the expropriation has occurred, documents and records within the host country will be in the control of an entity with the responsibility to minimize the company's affirmative recovery and to maximize the host country government's counterclaims. Here the lawyer can be of great help in listing and collecting, outside of the host country, the documents that will be needed. Business people, who will normally have a much better factual knowledge of the business than the lawyers, tend to underestimate gravely what it may take to develop a factual valuation case." 
tion clauses; force majeure clauses; conversion of currency clauses; payment of currency to offshore account clauses; and, dispute settlement clauses (including damages, interest rate, local remedies and waiver of sovereign immunity clauses). ${ }^{56}$ These enhanced contractual protections can either be negotiated into a contract between the investor and the home state ${ }^{57}$ or they are available under the applicable international investment agreement. The reason why these contractual strategies can be framed as "aggressive" is that such clauses are often one-sided and serve the sole interests of investors. To take an example, stabilization clauses, that limit the host state's ability to regulate, will ensure a high degree of certainty for investors but will not benefit the home state and, in the case of such particular clauses, it will most of the time lead to what is known as a "contractual regulatory chill" for host states.

\subsection{The "Mutually Beneficial" Approach: The Mutual Hostage Position}

In addition to "aggressive" strategies, businesses also have at their disposal "mutually beneficial" strategies to protect themselves against political risk that involve structuring the investment so that it is also beneficial for the host state by taking into account sustainable development. These strategies are rooted in the idea that "if the government, important local interest groups, and the public in general view the investment project favourably the government is less likely to enact negative changes in the investment legal framework". 58

In order to respond efficiently to political risk, recourse to soft law is crucial in light of the limited ability of hard law (IIAs, for example) to respond to political risk. Similarly, hard law is arguably not enough to ensure cooperation between investors and local communities in the perspective of insuring that the investment will be undertaken in a sustainable manner. In this respect, the cooperation of the investor on a voluntary basis is key. As explained above, when political risk is at issue, a more subtle and complex approach is required that takes into account the specific context of the investment and of the country, including its history and cultural heritage in order to identify the elements necessary to undertake cooperation with all the actors involved such as local

56 A detailed analysis of these provisions falls beyond the scope of this study. For an exhaustive study of these clauses, see generally Dolzer and Schreuer, op. cit. and M. Sornarajah, The Settlement of Foreign Investment Disputes (Kluwer 2000).

57 See generally Erlend Bakken and Tonje P. Gormley, "Using Dynamic Petroleum Contract Clauses to Manage Risk in Volatile Markets” in Karl Sauvant(ed.), Yearbookon International Investment Law \& Policy 2009-2010 (OUP 2010) 177-213.

58 Salacuse, op. cit., at 146. 
communities. ${ }^{59}$ The voluntary basis upon which investors undertake their operations in a sustainable manner sheds light on a form of strategic ethics rooted in what is known as the "ethics pays" principle. ${ }^{60}$ In other words, mutually beneficial strategies are guided by ethics that acts as a factor of profit, the purpose of corporations. In this context, ethics acts as a strategic instrument allowing a given corporation to ensure the perennity of its activity in line with the Marxist utilitarian conception of moral: the perennity of the corporation's activities lies in the involvement of the latter in beneficial initiatives with respect to local communities and the host state as a whole, leading to a "winwin" situation.

In order to undertake such mutually beneficial investments aiming at the reduction of political risk, it is important to structure the overall operation so that the government, local interest groups and the public in general can drain important benefits from the investment in order to create "mutual hostage positions": on the one hand, while the host government has leverage as a sovereign entity within its territory, if it interferes with the investment, it also negatively affects its own interests. On the other hand, if the investor does not participate to the host state's development by undertaking, for example, an environmental or labour-friendly investment, he will face higher political risk.

Reaching a "mutual hostage position" necessarily requires from the investor to integrate as much as feasible its investment in the host state by rendering it as local as possible and even try to give it a national identity by aligning it with national policies and goals. Such a strategy is in blatant contradiction with the "aggressive" strategies mentioned above that rather require integrating as little as possible the overall operation within the host country. Extensively integrating the investment in the host state can be frightening for businesses and might explain why it is not often an option chosen and less discussed in trade and investment law literature. Yet, and seemingly paradoxically, it is the most efficient option in order to mitigate political risk in a constructive manner.

Under this framework, the simple reduction of political risk and probability of state interference with an investor's operation act as an important incentive to encourage sustainability and lead businesses to operate consistently with environmental, labour and social objectives in addition to the economic enhancement that is inherent to FDI.

59 See Cécile Renouard, "La responsibility sociale des multinationales spécialisées dans l'extraction des minerais et hydrocarbures-Nouveaux enjeux éthiques et juridiques" (2008) 135 R.D.I. 485 , at 486. 
An example of such a strategy can be found in the minerals - and in particular hydrocarbons - extraction sector with numerous memorandums of understanding that were entered into between multinational corporations and the governments and / or local communities of the host states. For example, Total, active in the petroleum sector, concluded a MoU in 1993 with the local communities in Nigeria where it was undertaking its investment. The MoU, even if non-binding, essentially listed the contributions of the corporation with respect to the local communities and was subsequently detailed through memorandums signed in 1999, 2004 and 2007. ${ }^{61}$ Similarly, Rio Tinto Alcan, a corporation active in the extraction of bauxite in the west region of Ghana, entered into a comparable non-binding MoU with the District Assembly and a NGO to ensure the integration of its projects in the region's political program with respect to the development of the locality. ${ }^{62}$

It is noteworthy that these initiatives (MoUs), which are considered as instruments of development by the World Bank, ${ }^{63}$ are key for the moral engagement of the corporations they convey rather than for their contractual nature. It is indeed the strategic ethics-or the mutual hostage position-rational behind these instruments that ensure their respect by the parties involved and most notably by the investors.

Mutually beneficial approaches know, however, a very wide range of applications and are not limited to a particular sector or type of investment. For instance, as far as the protection of the environment is concerned, such strategies require investors to undertake commercial operations that are consistent with the host states' environmental objectives and policies. This is especially relevant and topical in the context of a post-2020 UN Framework Convention on Climate Change (UNFCCC) regime. For instance, Mexico, the first developing country to submit its new climate action plan for the UNFCCC, ${ }^{64}$ "identified a series of areas where technology transfer could be of benefit [to] the country for adaptation". ${ }^{65}$ In this regard, FDI, as "the traditional method of transferring

\footnotetext{
61 Id., at 490 et seq.

62 Ibid.

63 Id., at 493.

64 See United Nations Framework Convention on Climate Change, uN Climate Change Newsroom, available at http://newsroom.unfccc.int/unfccc-newsroom/mexico-submitsits-climate-action-plan-ahead-of-2015-paris-agreement/ (accessed 9 December 2015).

65 Mexico - Intended Nationally Determined Contribution, submitted on Mar. 30, 2015, available at http://www4.unfccc.int/submissions/INDC/Published\%2oDocuments/Mexico/1/ MEXICO\%20INDC\%2003.30.2015.pdf (accessed 9 December 2015) at 8. The INDC further lists several of such areas:
} 
technology", ${ }^{66}$ can undoubtedly help Mexico reach its post-2020 objectives in terms of environmental protection and if investors embrace this idea, they will essentially align their interests with Mexico's environmental policies, making it unlikely for the latter to interfere with the former's investments. ${ }^{67}$ The same applies for numerous aspects of countries' new climate action plans. One can think of Singapore, for example, which identifies as a weakness in its "intended nationally determined contribution" (INDC) its limited ability to "harness[] solar energy in a significant way, given its small size and dense urban landscape." ${ }^{68}$ Again, investors promoting the use of solar energy in their investment plans or undertaking transfers of technology related to solar energy will be adequately protected through the alignment of their interests with those of Singapore; an option that can prove to be less costly than the setting-up of a decentralized structure in an attempt to keep assets out of the host state's territory. By pursuing these strategies, through the alignment of interests, the

- Access to information systems in order to monitor hydrometeorological events in real time and thus consolidate and enhance early warning systems.

- Availability of methods and tools to assess climate impacts, vulnerability and adaptation in specific sectors and regions.

- Water technologies for savings, recycling, capture, irrigation and sustainable management for agriculture purposes.

- Transportation technologies that are resilient to the adverse effects of climate change in particular for roads and massive transportation.

- Technologies for the protection of coastal and river infrastructure.

66 David M. Haug, "The International Transfer of Technology: Lessons that Eastern Europe can Learn from the Failed Third World Experience" (1992) 5 Harvard Journal of Law \& Technology 209, at 213. See also Helen E. Weidner, "The United States and North-South Technology Transfer: Some Practical and Legal Obstacles" (1983) 2 Wis. Int'l L. J. 205, at 205: technology underdevelopment is one of the main causes of "basic internal problems such as inability to feed the local populations or to provide routine health services".

67 A similar argument can be made on the basis of Senegal's INDC, for example, that emphasises the financial and technological needs of the country (République du SénégalContribution Prévue Déterminée au Niveau National, submitted on Sept. 26, 2015, available at http://www4.unfccc.int/submissions/INDC/Published\%20Documents/Senegal/1/CP DN\%20-\%20Sénégal.pdf (accessed 9 December 2015) at 13).

68 Singapore - Intended Nationally Determined Contribution (INDC) and Accompanying Information, submitted on Jul. 3, 2015, available at http://www4.unfccc.int/submissions/ INDC/Published\%20Documents/Singapore/1/Singapore\%2oINDC.pdf (accessed 9 December 2015) at 3 . 
relationship between international free trade and investment rules and the protection of the environment could thus effectively become less conflictual. ${ }^{69}$

Furthermore, these mutually beneficial strategies are not limited to the improvement of environmental protection and have a great potential as far as labour is concerned. Indeed, the alignment of the investor's with a given state's interests can take place through the inclusion of nationals in the investment operation, either as partners in the overall operation or as contract suppliers. These strategies can also include appointing nationals of the host state to key managerial positions in the project, using national consultants, hiring personnel in the host state, and contracting with local companies. In addition, investors can sell equity in the project to nationals of the host state which would, in addition to enhancing the national image of the investment, align the interests of investors with those of the nationals: the success of the enterprise would benefit all. ${ }^{70}$ Investors can also consider leasing or financing assets with local creditors.

The rationale behind such strategies is obvious: the alignment of the investor's and the host state's interests. Moreover, it would also address the fact that unwanted interference of the host state with investments is more often than not triggered by societal pressure and "intensified by domestic perceptions about the way the benefits of investment are distributed between the foreigner and the local population".71 Local unions, citizens groups and nongovernmental organizations indeed often spark investor-state disputes and it is thus important to include them in the project or at least align the investment with their interests. ${ }^{72}$

69 Philippe Sands, "Sustainable Development: Treaty, Custom, and the Cross-fertilization of International Law", in Alan Boyle and David Freestone, International Law and Sustainable Development: Past Achievements and Future Challenges (OuP 1999), at 40:

"The classic area in which this [i.e. the potential conflict between norms] is arising is in regard to the relationship between international free trade rules and international environmental protection laws."

70 See Stansbury, op. cit., at 682 ("Partial local private sector ownership of the core business, where not required by local law in the host country, may provide some political protection against the likelihood of expropriation").

71 Rubins and Kinsella, op. cit., at 5 .

72 It is noteworthy that in the Tecmed case (Tecnicas Medioambientales Tecmed S.A. $v$ The United Mexican States, ICSID (W. Bank) ARB(AF)/oo/2 (Award) (29 May 2003)), the expropriation of the investor's investment took place after the local population's protests led the Mexican government to enact the measures that sparkled the dispute. 
4 Conclusion

The world community's interest in international trade and investment law is often sparked by high profile cases involving millions of dollars in claims and featuring states as being unable to legitimately regulate in the public interest when faced with ever-more powerful and profit-oriented businesses. As such, investment law is sometimes perceived as a field of law inherently aggressive and hostile where private actors are demonized. Such a short-sighted view fails to take into account, however, the thousands of operations that take place under the auspices of the complex international economic law framework and that never give rise to any kind of disputes and that allow businesses to undertake their international commercial operations while positively contributing to states' economic and political development.

On the other hand, concerning FDI that have given birth to disputes this paper argues that they could have been avoided by taking into account what is known as "obsolescing bargains", through effective political risk assessment and constructive strategies based on sustainability by opposition to aggressive strategies consisting in putting the host state in a hostage position via structural or contractual artefacts. Such strategies are available to businesses in order to minimize political risk and, ultimately, the probability of a dispute. Educating foreign trade actors - including investors - on the existence and use of such strategies - which is partly the responsibility of policy makers — seems critical in light of economic globalization, the increasing economic power of emerging markets that are the first recipients of foreign investments, and the rise in the number of international trade cases filled every year. 